ISSN 2078-6441. Вісник Львівського університету. Серія географічна. 2014. Випуск 47. С. 50-57. Visnyk of the Lviv University. Series Geography. 2014. Issue 47. P. 50-57.

55:502.64:624.131.1

\author{
етро олошин \\ ьвівський н ціон льний університет імені в н рнк, \\ вул. . рушевського, 4, 79005, м. ьвів, кр їн
}

озглянуто основні чинники, які вплив ють н стійкість п м'яток рхітектури. 'ясов но, що серед природних чинників провідну роль відігр $\epsilon$ н явність в ктивній зоні споруд грунтів з сенсорними вл стивостями, т кож суттєві зміни цих вл стивостей під впливом техногенного пресу. о техногенних н леж ть головно конструктивні особливості споруд, види будівельних м тері лів т їхній вік.

лючові слов : п м'ятк рхітектури, стійкість, деформ ція, фунд менти, геологічне середовище, вл стивості грунтів.

исок соці льн зн чимість проблем збереження п м'яток рхітектури, розробк н уково обгрунтов них проектів їхньої рест вр ції, потребує глибокого н лізу природних і нтропогенних чинників, які вплив ють н їхню стійкість. йгострішою і н й кту льнішою ця проблем є для об'єктів історичної сп дщини, розт шов них у центр льній ч стині ьвов , з несеній до списку всесвітньої сп дщини

ей ст тус передб ч є їхнє збереження й охорону. дн к сконцентров ний тут величезний культурно-історичний потенці л м $є$ низку проблем, які потребують н г льного вирішення. йгострішою $\mathrm{T}$ н й кту льнішою $є$ проблем фізичного збереження п м'яток. ля пон д $70 \%$ розт шов них тут будівель, що м ють велику історичну цінність, х р ктерний різний ступінь ушкодження, окремі з них з зн ли повного руйнув ння.

дним 3 н йв жливіших з вд нь охорони п м'яток є з безпечення їхньої стійкості. ід стійкістю розуміють зд тність їхніх основних несучих конструкцій чинити опір зусиллям, спрямов ним н виведення п м'ятки зі ст ну ст тичної рівнов ги [3].

м'ятки рхітектури треб розгляд ти як скл дні природно-технічні системи, які охоплюють тісно вз ємопов'яз ні між собою конструктивні елементи й окремі скл дові природного середовищ .

ровідну роль у з безпеченні стійкості п м'яток відігр є геологічне середовище, яке використовують як підгрунтя фунд ментів споруд.

сфері впливу історико- рхітектурних п м'яток $з$ ляг є строк тий $з$ літологічним скл дом і вл стивостями комплекс грунтів, який містить суч сні н гром дження (культурний ш р), відкл ди четвертинної системи, неогену т верхньої крейди.

ороди культурного ш ру суцільним пл щем покрив ють територію історичної ч стини ьвов . отужність ш ру змінюється в широких меж х - від 2,0-4,0 до 6,0-9,0 м. схил х улоговини вон пересічно не превищує 3,0-4,0 м, в 3 пл ві річки, зокрем поблизу її русл , подекуди досяг є 7,0-9,0 м. ілянки з товщиною культурного

(C) олошин ., 2014 
ш ру, що перевищує 3,0 м, 3 йм ють пон д $50 \%$ г г льної площі. пересічної глибини 3 ляг ння фунд ментів 2,0-3,0 м він є підгрунтям б г тьох п м'яток рхітектури.

ет льні дослідження культурного ш ру у свердловин х, шурф х, будівельних котлов н х, тр ншеях, рхеологічних розкоп х з свідчили, що це унік льне природнонтропогенне утворення зі скл дною внутрішньою будовою, строк тим літологічним і хімічним скл дом т фізико-мех нічними й корозійними вл стивостями. ідкл ди цього генетичного типу м ють яскр во вир жені сенсорні вл стивості, зумовлені н явністю в їхньому скл ді низки ефемерних елементів (орг нічної речовини, легкорозчинних солей тощо), дуже чутливих до природних т , особливо, нтропогенних змін умов існув ння [2].

р ктерною особливістю грунтів є вкр й високий ступінь неоднорідності скл ду, ст ну і вл стивостей як у пл ні, т к і 3 глибиною. літологічному скл ді з г лом перев ж ють суглинки, проте в 6 г тьох місцях тр пляються піски, супіски т глини.

йже постійним їхнім супутником є бит цегл, будівельне і побутове сміття, кер мік , скло, ул мки дерев , шкіри, костей тощо.

люві льному комплексі з особливостями умов н гром дження, літологічним скл дом т вл стивостями виділено руслові, з пл вні т ст ричні (болотні) відкл ди.

условий лювій предст влений дрібно- т середньозернистими піск ми з лінз ми і прош рк ми гр війно-г лечникового м тері лу. ідкл ди цієї генези поширені головно у пр вобережній ч стині долини олтви. іiї лівому березі вони фіксов ні лише у вигляді невеликих з площею плям. ересічн потужність ш ру ст новить 3,5-6,5 м. і н гром дження м ють високі пок зники мех нічних вл стивостей.

пл вний лювій скл дений супіск ми т суглинк ми 3 прош рк ми і лінз ми дрібного піску, іноді з домішк ми орг нічних речовин. овщин ш ру порід цього типу н гром джень колив ється від 1,0 до 3,0 м. ех нічні вл стивості дост тньо високі.

ідкл $\partial и \mathrm{~cm}$ ричного лювію з йм ють більше третини досліджув ної території. осереджені вони головно н лівому березі олтви, т кож формують днищ долин iii приток. ітологічно вони предст влені з торфов ними суглинк ми, глин ми і торф ми. орфи з ляг ють у вигляді окремих лінз товщиною від 0,2 до 1,0-2,4 м.

йбільше іх виявлено н пр. вободи, вулицях нковій, в н р нк, овжун . торфов ні породи у вигляді л нцюжк ізольов них м сивів простяг ються вздовж лівого берег олтви. йбільші з потужністю ш ри (6,0-12,0 м) виявлено поблизу пл. іцкевич , вул. н тюк , н ділянці розт шув ння е тру опери і б лету.

ороди цього генетичного типу з вдяки високому вмісту орг ніки м ють низькі пок зники мех нічних вл стивостей, розвиток процесів трив лої консолід ції, високу чутливість до нтропогенного впливу, зокрем обезводнення т вібр ції.

елюві льні н гром дження скл дені лесовими супіск ми твердої і пл стичної консистенції з прош рк ми пісків, які досить потужним ш ром (від 1,0-3,0 до 10,0-15,0 м) укрив ють схили гори ит дель. они щільні й м ють високі пок зники мех нічних вл стивостей.

еогенові відкл $\partial и$ зі стр тигр фічним неузгодженням 3 ляг ють н розмитій поверхні верхньокрейдових мергелів т корі їхнього звітрюв ння. они скл дені дрібними кв рцовими піск ми 3 прош рк ми пісковиків. ляг ють у вигляді невеликих м сивів н схил х вятоюрської, мкової гори т гори ит дель.

езв ж ючи н високі пок зники мех нічних вл стивостей, вони схильні до розвитку процесів мех нічної суфозії. 
гром дження верхньої крейди н леж ть до м стрихтського ярусу (львівськ світ ) і предст влені т к зв ними львівськими мергелями. ідкл ди верхньої крейди поширені н всій території. либин їхнього з ляг ння тісно корелює з рельєфом. схил х улоговини вони є н глибині 1,5-3,0 м, н ділянк х н йбільшого ерозійного врізу долини олтви - н глибин х від 6,0 до 15,0 м. ергелі звітрілі, тріщинув ті. тупінь тріщинув тості з кономірно зменшується з глибиною. ок зники вл стивостей змінюються в широкому ді п зоні, з лежно від ступеня звітрілості, проте з г лом м ють високі зн чення мех нічних вл стивостей. верхній, н йбільш звітрілій ч стині, мергелі поступово змінені глинистим елювієм - твердими т н півтвердими к рбон тними суглинк ми і глин ми. они досить щільні, уміщують ул мки мергелю, кількість якого зрост є з глибиною. отужність ш ру глин змінюється від 0,5 до 4,0 м.

ідземні води. досліджув ній території виявлено дв водоносні горизонти: четвертинний і верхньокрейдовий.

ерший від поверхні - водоносний горизонт четвертинних відкл дів, який сформув вся н водотривкому елювії верхньокрейдових мергелів.

одовмісними пород ми є строк тий з літологічним скл дом комплекс люві льних відкл дів олтви. оди горизонту безн пірні. они з ляг ють перев жно н глибин х 2,0-4,0 м. ише н ділянк х штучного дрен жу ( е тр опери і 6 лету, пл. итн, т кож н схил х г. ит дель) глибини з ляг ння перевищують 6,0-9,0 м. периферійних ч стин х долини олтви відкл ди пр ктично безводні.

отужність водоносного горизонту змінюється від 0,5-3,0 до 8,0 м. більшості вип дків вон не перевищує 2,0-3,0 м.

ивлення водоносного горизонту відбув ється вн слідок інфільтр ції тмосферних оп дів, ч сткового розв нт ження вод верхньокрейдового водоносного горизонту т витоків з інженерних мереж.

ля вод х р ктерн середня т сл бк 3 г льнокислотн, вуглекислотн т сульф тн гресивність до м тері лу з глиблених будівельних конструкцій. вдяки високому вмісту в них солей різного типу і к пілярному підсмоктув нню цих вод відбув ється ктивне н гром дження у будівельному м тері лі мінер лів-руйнівників (бішофіту, тен рдиту, мір біліту, гіпсу т ін).

ругим від поверхні є горизонт верхньокрейдових ртезі нських вод, пов'яз них з тріщинув тими мергелями м стрихтського ярусу.

либин $з$ ляг ння гідрост тичного рівня вод цього горизонту змінюється від 2,8 м н вул. нківській до 11,6 м н вул. . ривонос .

н чення н пору т кож колив ється в широких меж х. p йоні ялькового те тру води ф ктично безн пірні, у свердловин х н пр. вободи н пір досяг є 9,5-10,3 м. ересічно він ст новить 2,0-4,0 м.

комплексом чинників (рельєф, будов геологічного розрізу, потужність культурного ш ру, з торфов них порід і торфів, гідрогеологічні умови, суч сні морфодин мічні процеси) у центр льній ч стині міст виділено 19 типів геологічного середовищ . росторовий н ліз їхнього поширення з свідчив, що н схил х улоговини перев ж ють порівняно стійкі до сприйняття н в нт жень від будівель його типи. ля них $\mathrm{x}$ р ктерн н явність в основі фунд ментів порід 3 високою несучою зд тністю, відсутність, з звич й, грунтових вод і незн чний розвиток морфодин мічних процесів. ещо менші 3 площею території 3 йм ють ділянки 3 порівняно несприятливими умов ми. они м ють потужну (3,0-6,0 м) товщу техногенних (сильно і нерівномірно стискув них порід) т розвиток мех нічної суфозії. йбільш несприятливі умови 
прит м нні днищу улоговини. ут перев ж ють ділянки з 6 г тош ровою будовою розрізу, потужною товщею техногенних $(3,0-9,0$ м), з торфов них грунтів і торфів, товщиною до 6,0-8,0 м, ктивним розвитком процесів підтоплення, дренув ння т мех нічної суфозії.

ехногенн скл дов історичних природно-технічних геосистем ( $\quad)$ - це скл дний композит, який охоплює житлові будинки, дміністр тивні й культові споруди тощо.

осліджув ний $\mathrm{p}$ йон м є щільну різноповерхову з будову. ут розміщені будівлі висотою від одного до восьми поверхів. сновн їхня кількість (97\%) м є висоту від одного до чотирьох поверхів. ровідну роль відігр є триповерхов з будов (40,7\%).

удинки збудов но н фунд мент х мілкого (стрічкові, плитні) т глибокого (п льові) 3 кл д ння. еред фунд ментів мілкого $з$ кл д ння н йч стіше тр пляються фунд менти типу “стін в грунті” т з розширеною п'ятою. м тері лом їх поділяють н цегляні, бутові н в пняному розчині т бетонні. p ктерною особливістю стрічкових фунд ментів є широке використ ння дерев . одних місцях це дощ ні н стили, іноді з піщ ною подушкою, в інших - н стили з дерев'яних л г. круглі, кв др тної бо прямокутної форми з поперечним перерізом від 10,0 до 30,0 см.

иявлено н стили суцільні й переривч сті, одно- бо двоярусні. они орієнтов ні вздовж, упоперек т під кутом до осі фунд ментів. ерідко тр пляються конструкціі комбінов ного типу. они містять суцільний бо переривч стий дощ ний н стил т поздовжні бруси. тері лом дерев'яної скл дової фунд ментів $є$ дуб. ирин фунд ментів - від 0,7 до 2,7 м.

льові фунд менти вл штовув ли із дерев'яних п ль від 10,0-15,0 до 20,0-30,0 см у ді метрі. сто тр пляються поля 3 коротких пір мід льних п ль довжиною 1,0-1,5 м, які використовув ли для з г льного ущільнення порід підв лин. иготовлені вони перев жно з дуб , ле тр пляються й соснові т березові.

либин $з$ кл д ння стрічкових фунд ментів пересічно не перевищує 3,0 м. овжин п ль - 3,0-6,0 м.

росторовий н ліз типів фунд ментів з свідчив, що н схил х долини р. олтв де поширені перев жно породи культурного ш ру зн чної потужності т , меншою мірою, з торфов ні грунти і торфи сум рною товщиною під фунд мент ми 2,0-3,0 м, використовув ли стрічкові фунд менти 3 дерев'яними н стил ми різного типу т фунд менти у вигляді суцільної бетонної плити товщиною 0,9-1,2 м. p йон х, де в підгрунті з ляг ють грунти з високими пок зник ми мех нічних вл стивостей, використовув ли фунд менти типу “стін в грунті”. зн чимо, що цей тип фунд ментів виявлено і н ділянк х зі скл дними умов ми.

ділянк х $з$ великою потужністю “сл бких” грунтів з стосовув ли, з звич й, п льові фунд менти.

т тичне н в нт ження н грунти (з лежно від поверховості будівель) колив ється від 0,1 до 0,3

метою оцінки ст ну техногенної скл дової досліджув них природно-технічних систем викон но дет льне обстеження споруд з вивченням ступеня їхнього ушкодження. цією озн кою будівлі розділено н декільк к тегорій: 1) без видимих деформ цій; 2) з тріщин ми у несучих стін х до 3,0-5,0 мм, що не порушують їхньої норм льної експлу т ції; 3) з тріщин ми до 20,0-30,0 мм, прогин ми т перекос ми, які нег тивно вплив ють н ст н будівель; 4) в рійні будівлі - у яких ступінь ушкодження конструкцій не г р нтує цілісності споруди.

езульт ти оцінки технічного ст ну будинків і споруд н ведено у т блиці 
т н будівель і споруд центр льної ч стини ьвов

\begin{tabular}{|c|c|c|}
\hline т н будівель & ількість & $\begin{array}{cc} & \text { ідсоток від } \\
3 & \text { г } \\
\text { льної кількості }\end{array}$ \\
\hline удівлі без ушкоджень & 169 & 13,7 \\
\hline удівлі з тріщин ми до 3,0-5,0 мм & 723 & 58,4 \\
\hline удівлі з тріщин ми до 20,0-30,0 мм & 98 & 7,9 \\
\hline в рійні будівлі & 248 & 20,0 \\
\hline г льн кількість будівель & 1238 & 100,0 \\
\hline
\end{tabular}

к 6 чимо з т блиці, велик кількість будівель, у тому числі і п м’яток рхітектури, втр тил свою стійкість і м є той чи інший ступінь ушкодження несучих елементів, $20 \%$ із них з грожують повним руйнув нням.

стійкість п м'яток рхітектури суттєво вплив ють т кож конструктивні схеми їхніх н дземних ч стин, види будівельних м тері лів, ч с функціонув ння. н чну кількість будівель протягом ч су існув ння реконструюв ли, перебудовув ли, підсилюв ли тощо.

ричини, що призводять до втр ти стійкості будівель і споруд, поділяють н дві великі групи [1]:

1) прит м нні с мій споруді (конструктивні);

2) пов'яз ні з дією зовнішніх природних т нтропогенних чинників н споруду. о перших н леж ть конструктивні дефекти, помилки в ході будівництв, типи будівельних м тері лів, їхнє ст ріння т ін.

о другої групи причин н лежить ущільнення грунтів, зумовлене впливом ст тичних і дин мічних н в нт жень, дегідр т цією, розвитком процесів повзучності т консолід ції, мех нічної т хімічної суфозії, окиснення орг нічних решток у грунт х тощо.

звич й, деформ ції будинків і споруд зумовлені сукупним нег тивним впливом комплексу чинників першої т другої груп.

росторовий н ліз геолого-гідрогеологічних умов, типів т конструкцій фунд ментів 3 свідчує, що окремі природні з грози (скл д і вл стивості підгрунтя фунд ментів) були ч стково вр хов ні під ч с проектув ння т будівництв 3 вдяки використ нню різних типів фунд ментів, зменшенню товщини ш ру сл бких грунтів, вл штув нню штучних (піщ них) подушок, регулюв нню н в нТ ження н грунти, з стосув нню спеці льних конструктивних з ходів. томість зміни ст ну і вл стивостей геологічного середовищ, зумовлені довготрив лим т різном сшт бним зовнішнім впливом, не вр ховув ли.

ля виявлення провідних чинників, що визн ч ють стійкість будівель, викон но комп'ютерне н кл д ння оцінних к рт (к рт чинників) н к рту в рійності-стійкості. ідр ховув ли площі окремих виділів чинник, з г льну кількість будівель у його меж х і кількість ушкоджених споруд, що прип д $є$ н цей виділ. стк від ділення кількості в рійних будинків до їхньої з г льної кількості н площі виділу д в л коефіцієнт стійкості ( $c$ ). бсолютне зн чення коефіцієнт озн ч є ступінь впливу того чи іншого чинник н стійкість споруди.

коефіцієнтом стійкості оцінюв ли вплив н ст н споруд т ких вл стивостей геологічного середовищ, як глибин з ляг ння мергелів, грунтових вод (техногенного підтоплення і дренув ння), потужність грунтів культурного ш ру, з торфов них порід i торфів т скл дність інженерно-геологічних умов. рім того, бр ли до ув ги зміни 
геологічного середовищ, зумовлені розвитком процесів суфозії, дегідр т ційного ущільнення, повзучості т консолід ції глинистих і орг но-мінер льних грунтів. росторовий н ліз розподілу сильно деформов них т в рійних споруд з свідчив, що вони приурочені головно до з пл вної ч стини р. олтв т контурів ліквідов них оборонних споруд, зокрем, оборонних ровів. першому вип дку це ділянки зі скл дною, б г тош ровою будовою геологічного середовищ 3 перев ж нням у ній грунтів з низькими пок зник ми мех нічних вл стивостей. другому - ділянки з потужною (до 6,0-9,0 м) товщею грунтів культурного ш ру, які т кож м ють низькі пок зники і в меж х яких, крім того, розвив ються процеси мех нічної суфозії, дегідр т ційне ущільнення т ущільнення, зумовлене впливом вібродин мічних н в нт жень. пільною рисою цих двох к тегорій ділянок $є$ н явність у їхній будові порід з сенсорними вл стивостями, дуже чутливих до зовнішнього впливу.

інім льні зн чення коефіцієнт стійкості будівель с 3 фіксов но н ділянк х з близьким від поверхні з ляг нням мергелів $(0,36)$. місцях, де мергелі з ляг ють н глибині пон д 10,0 м, він зрост є до 3,08. томість, у місцях розвитку процесів підтоплення його зн чення збільшується до 14,4. йяскр віше виявляється зв'язок стійкості зі скл дністю будови геологічного середовищ . ділянк х, де безпосередньо під фунд мент ми з ляг ють мергелі, коефіцієнт стійкості дорівнює нулю. місцях, де в геологічному розрізі з ляг є потужн товщ техногенних т $з$ торфов них грунтів і торфів, він досяг є 30,4-40,7.

кремо з зн чимо, що втр т стійкості будівель ч сто пов'яз н 3 деструкцією дерев'яних елементів фунд ментів, зумовлен техногенним зниженням рівня грунтових вод. дним із техногенних чинників, що х р ктеризує стійкість п м'яток, є їхній вік. ін певною мірою зумовлює комплекс технічних причин і перш 3 все процеси ст ріння будівель, втомлюв ність будівельних м тері лів, неф хові реконструкції. исокий коефіцієнт в рійності $(28,4)$ з фіксов но для з будови - V ст., для споруд $\mathrm{V}-\mathrm{V}$ ст. він ст новить $30,0, \quad$ ст. $-14,6$.

ольові обстеження деформов них споруд з свідчили, що одним із н йпотужніших чинників, який призводить до втр ти стійкості п м'яток, є нтропогенн мех нічн суфозія. он розвив ється головно у н йсприятливішій з скл дом і вл стивостями товщі техногенних грунтів. йч стіше її прояви фіксують у місцях ушкодження к н ліз ційних колекторів, у сфері впливу яких простежується вимив ння дрібнозему. ї прояви фіксують пр ктично н всій досліджув ній території, де нез довільно функціонує систем водовідведення [4].

ей процес 3 погляду впливу н стійкість споруд $є$ н йбільш 3 грозливим. видкість його розвитку н ділянк х зі сприятливими умов ми н дзвич йно висок . творення небезпечного для споруди осід ння чи пров люв ння грунту може відбув тися протягом одного бо декількох років. роцес розвив ється, з звич й, прихов но, ре ліз ція відбув ється м йже миттєво і тому є вкр й небезпечною не лише для споруд, й для людей.

жливим чинником деформ цій будівель, що зумовлені техногенними змін ми геологічного середовищ, зокрем, зниженням рівня грунтових вод, є руйнув ння дерев'яних скл дових фунд ментів.

икон ний н ліз з свідчує, що втр т стійкості п м'яток рхітектури в центр льній ч стині міст зумовлен перш $з$ все комплексом геологічних причин. ей комплекс охоплює низку пор генетично пов'яз них між собою чинників, т ких як умови 
з ляг ння грунтів, н явність у геологічному розрізі порід із сенсорними вл стивостями, положення рівня грунтових вод, його дин мік .

Дн к н йв жливішим у цьому р зі є не тільки і н віть не стільки н явність в ктивній зоні фунд ментів сильностискув них, 3 низькою міцністю, суфозійно нестійких грунтів, що с мо по собі т кож дуже в жливо, проте здебільшого вр хов но в ході будівництв, суттєві зміни цих вл стивостей під впливом щор з більшого й урізном нітненого нтропогенного впливу т нез довільної експлу т ції будівель і мереж, які супроводжуються розвитком низки необезпечених інженерно-геологічних процесів. о т ких процесів перш 3 все н леж ть мех нічн суфозія т повільне нерівномірне осід ння земної поверхні, т кож вплив гресивного середовищ н підземні інженерні конструкції.

тже, проведені дослідження д ють змогу зробити т кі висновки.

1. орушення стійкості п м'яток рхітектури історичної ч стини ьвов зумовлене впливом комплексу природних і техногенних чинників. еред природних чинників провідну роль відігр ють будов , скл д, ст н і вл стивості геологічного середовищ . окрем , н явність в ктивній зоні споруд сильно стискув них, з низькою міцністю, схильних до розвитку процесів консолід ції т об'ємної повзучості, суфозійно нестійких грунтів. йв жливішим у цьому р зі є не тільки і не стільки н явність в ктивній зоні споруд грунтів з сенсорними вл стивостями, що дуже в жливо, суттєві зміни цих вл стивостей під впливом щор з більшого техногенного пресу, який зумовлює ктивний розвиток деформ ційних процесів.

2. о техногенних чинників з безпечення стійкості п м'яток н леж ть головно конструктивні особливості споруд, види будівельних м тері лів т їхній вік. ровідну роль у цьому р зі відігр ють фунд менти, перш 3 все їхня зд тність витримув ти н в нт ження від споруд в умов х змін вл стивостей геологічного середовищ .

йбільше будівель, що з зн ли недопустимих деформ цій, м ють фунд менти т н дфунд ментні ч стини будівель 3 дерев'яними елемент ми т фунд менти 3 дерев’яних п ль. мін водно-повітряного режиму їхнього існув ння, зумовлен зниженням рівня грунтових вод, супроводжується ч стковою бо повною деструкцією деревини. евну роль у з безпеченні стійкості відігр є вік п м'яток, який сум рно відобр ж є суттєве зменшення пок зників вл стивостей будівельних м тері лів.

1. ойко . . и гностик повреждений и методы восст новления эксплут ционных к честв зд ний / . . ойко. - ., 1975. - 175 с.

2. олошин. . р ктеристик культурного ш ру історичної з будови ьвов / . . олошин // ук. вісн. ернів. ун-ту. еогр фія. - 2003. - ип. 167. - . 29-37.

3. шкин . . и гностик деформ ций п мятников рхитектуры / . . шкин, . . ессонов. - . : тройизд т, 1984. -149 с.

4. Wołoszyn . Wpływ warunków geologiczno-in ynierskich na zachowanie zabytków architektury centralnej części Lwowa / . Wołoszyn // Biuletyn Państwowego In-tu Geol. - 2011. - Vol. 446 (1). - S. 157-162.

m ття: н дійшл до ред кцї̈ 08.09.2014

доопр иьов н 19.09 .2014

прийнят до друку 15.10.2014 


\section{ANALYSIS OF INFLUENCE OF NATURAL AND TECHNOGENIC FACTORS ON ARCHITECTURAL MONUMENTS SUSTAINABILITY WITHIN HISTORICAL CENTRE OF LVIV}

\section{Petro Voloshyn}

Ivan Franko National University of Lviv, M. Grushevskogo Str., 4, UA - 79005, Lviv, Ukraine

The main factors that influenced on sustainability of architectural monuments were considered. Among natural factors principle role belongs to presence of soils with sensor features in buildings active zone, and significant changes of those features under influence of technogenic press. Constructive features of buildings, kinds of building materials and their age belong to technogenic factors.

Key words: architectural monument, sustainability, deformation, basement, geological environment, soil features. 